DOI https://doi.org/10.30525/978-9934-26-039-1-12

\title{
МОВНА РЕПРЕЗЕНТАЦІЯ ХАРАКТЕРУ ЛЮДИНИ В УКРАЇНСЬКИХ ТА РОСІЙСЬКИХ ЗООФРАЗЕОЛОГІЗМАХ
}

\author{
Петрик О. М. \\ кандидат філологічних наук, \\ доцент кафедри слов'янської філології, \\ компаративістики та перекладу \\ Ніжинського державного університету імені Миколи Гоголя
}

Бюкерт Н. В.

магістрантка I курсу спеціальності 035 Філологія (035.03 слов 'янські мови та літератури (переклад включно), перша - російська))

Інституту філологіï, перекладу та журналістики Ніжинського державного університету імені Миколи Гоголя м. Ніжин, Чернігівська область, Украӥна

Антропоцентричний принцип побудови мовної, зокрема фразеологічної, картини світу є одним із найважливіших $[1 ; 2 ; 5]$. Людина намагається репрезентувати себе як вихідну точку відліку, яка автономна й незалежна від інших «центрів» і яка через це конкурує з ними. Проте представлена вона в українській та російській фразеологічних системах зооморфно, тобто для iї характеристики використовуються номінації назв тварин.

Тварина знаходиться в центрі світу людини, i тому іï (тварини) життєдіяльність у трансформованому вигляді стала основою для створення «еталонної шкали». Під час аналізу фразеологічних систем різних мов, як зазначає О. Левченко, стає очевидним, що еталоном для оцінювання людини $\epsilon$ створені нею ж уявлення про тваринний світ зооієрархія [1, с. 40].

Кількісні характеристики фактичного матеріалу (578 одиниць) [3; 4] підтверджують думку про антропоцентризм у фразеологічній системі української та російської мов: в аналізованих одиницях репрезентована семантика, яка так чи інакше маніфестує сему «людина», оскільки сама вона стоїть у центрі фразеологічного значення. У межах аналізованого матеріалу чітко виокремлюється чотири групи: 1) зовнішні ознаки людини, 2) риси характеру людини, 3) стан людини, 4) діяльність людини. 
Детально розглянувши групу риси характеру людини, констатуємо, що інтегрувальною ознакою $\epsilon$ «індивідуально-своєрідні якості особистості, що виявляються в поведінці, діяльності та ставленні до людей, колективу, до себе, речей, роботи». Видільною ознакою цієї групи $\epsilon$ те, що вказані підгрупи сформовані на основі діаметрально протилежних понять, наприклад, добрий / злий, сміливий / боягузливий та ін. Проте до складу майже всіх мікрогруп входять в основному лише негативно конотовані фразеологічні одиниці:

- працьовитість / лінощі: пращює як кінь (важко, виснажливо працює) - сонна тетеря (про ледачу людину) // ломовая лошадь (много и тяжело работающий) - колобкова корова (о неопрятном, ленивом человеке).

Найтиповішим компонентом підгрупи виступає елемент кінь. Образ коня є характерним для національної специфіки української і російської усної поетичної творчості, оскільки з давніх-давен він був помічником i супутником людини. За міфологічними уявленнями, це втілення вітрів, бурі, хмар, сонця, символ неприборканої сили. Цей образ символізує працьовитість, волелюбність, нескореність, швидкість, силу, вірність, здоров'я.

- щедрість / жадібність: кинутися як вовки на вівцю (жадібно); як кім на мишу (жадібно, пристрасно); як собака на сіні (той, хто сам не користується чим-небудь й іншим не дає) // волчий апnетит (беспредельная жадность, алчность); жаден, как волк (про жадного человека); любит как собака палку (о человеке, который сам не пользуется чем-либо и другим не даёт пользоваться).

Найуживаніший зоонім у цій підгрупі - вовк. Проте семантику фразеологізмів формує не стільки зоонім, скільки описувана ситуація та пара компонентів (вовк / вівия, кіт / миша, собака / палка). Вовк - символ зла, жадібності, жорстокості, лицемірства, брехні, кровожерливості. Він майже завжди зображується як нерозумний, зажерливий хижак-невдаха, проте в деяких фразеологізмах представлений 3 позитивного боку, уособлюючи бувалу, досвідчену людину.

- турбота / безтурботність, безвольність, покірність: боже теля (дуже спокійна, лагідна, але безвольна, інертна людина); зайчики в голові стрибають (хто-небудь легковажний, безтурботний); ні риба ні м'ясо (безвольна, безхарактерна людина) // божья коровка (кроткий, безобидный, не умеющий постоять за себя человек); мокрая курица (безвольный, бесхарактерный человек); куриная слепота (о легковерном, наивном человеке).

Активно функціонують у цій мікрогрупі компоненти теля із семою недосвідчений, безвольний, покірний та курииа із семою безвольный. 
У російській фразеології з незапам'ятних часів курка була предметом жартівливих насмішок. Вона не літає, хоча має крила, не в'є гнізда, боїться води, не бачить в темряві, полохлива, дурна, незграбна. Найчастіше образ курки використовується в іронічному сенсі, де мова йде про людину з негативними рисами характеру.

- хоробрість / боягузтво: не $з$ заячого пуху (хоробрий, сміливий); скрутить волові шию (роги) (надзвичайно сильний, дужий); заяча душа (боязка, полохлива людина) // смельий, как сокол (про смелого, отважного человека); на ружьё глядит, а от воробья бежит (о трусоватом, ненадёжном и плутоватом человеке); трусливый, как заяц (лань) (боязливый, пугливый человек).

Типовим маркером семи боязкий, полохливий виступає в обох мовах компонент заєць, що символізує наляканість, хоча, за віруваннями давніх слов'ян, він уявлявся, як образ чорта. Відомий російський етнограф Д. Зеленін писав про зоонім заєць: «У забобонах та різних повір'ях $є$ багато таких, які явно створені не в мисливському середовищі, в усякому випадку - не первісним мисливцем. Таке, приміром, повір'я про близькість зайця до нечистої сили». Зустріч із зайцем вважалася поганою прикметою у всіх слов'ян, у Германії та Франції. Незважаючи на це в українському та російському фольклорі заєць представлений із симпатією. За нього, хоч він і виступає символом боягузтва, зазвичай заступаються герої казок. I в казках, і у фразеології заєць зовсім не пов'язаний із нечистою силою, а лише маніфестує боягузтво.

- доброта / злість, грубощі: мухи не скривдить (хто-небудь дуже добрий, сумирний, лагідний); підшитий собаками (дуже злий); пошитися в собачу шкуру (зробитися невгамовно злим, недоброзичливим) // комара не зашибёm (никого не обидит кто-либо); гад ползучий (злой, скверный человек); собачья душа (скверный, грубый человек; хам); Змей-Горыныч (воплощение зла, коварства и насилия в образе страшного змея); змея подколодная (злобный, отвратительный человек); собачья душа (скверный, грубый человек, хам).

Яскравими маркерами семи злий виступають в обох мовах зооніми змія та собака. Хоч у Біблії змія символізує мудрість, проте в аналізованому матеріалі в першу чергу актуалізується сема nidступність, злостивість. Компонент собака дає найбільшу кількість негативних конотацій: оскільки ця тварина насамперед сторож господарства, то вона асоціюється зі злістю, собаку тримають в неволі, у будці й на ланцюгу (живе, як собака), собаку беруть на полювання, де він набігає не одну версту (втомився, як собака). Крім того, сема зло асоціативно виявляється у близькості до вовка і тому до чорта (диявола). 
- чесність / хитрість, лицемірність: старий вовк, старий лис, стара лисиця (хитра людина, яка зазнавала в житті багато негод, нестатків i набула житейської мудрості, досвіду і знань); надягати овечу шкуру (лицемірно приховувати під маскою доброзичливості свої підлі наміри, діi); гратися в кота і мишку (мишу) (хитрувати, затаювати що-небудь); знати, де раки зимують (бути хитрим, спритним); підшитий лисом (дуже хитрий) // стреляный воробей (очень опытный человек, которого трудно провести, обмануть или удивить); волк в овечьей шкуре (человек, прикрывающий свои дурные намерения, действия маской добродетели, лицемер); колорадский жук (о лицемерном, коварном человеке); извиваться ужжом (хитрить, изворачиваться, пытаясь оправдать себя); лиса Патрикеевна (лукавый, хитрый, пронырливый человек, проныра, льстец); гусь лапчатый (хитрый, пронырливый человек).

Найтиповішим виразником ознаки хитрий є зоонім лисиия. В обох мовах лис виступає символом підступності, лукавості. Проте цікавим $\epsilon$ той факт, що в деяких фразеологізмах ця риса характеру має позитивну оцінку, напр.: старий лис; стара лисиця (хитра людина, яка зазнавала в житті багато негод, нестатків і набула житейської мудрості, досвіду і знань).

- гордощі: гордий як гусак (про гордовиту людину); мухи в носі грають (про гордовиту, задерикувату людину); на коні (на козі) не nid’їеш (хто-небудь дуже гордовитий, пихатий); ходити півнем (триматися зверхньо, гордовито, хоробро) // ходить гоголем (ходить «задрав нос», посматривать на всех свысока), важный как гусь (важный человек).

Для виділеної підгрупи частотним є компонент гусак. Хоча у світовій культурі це виключно позитивний символ, у слов'янському фольклорі гусак постає дещо простакуватим, балакучим, дурним та пихатим, що й спричинило вияв зафіксованої семантики фразеологічної одиниці.

Отже, окреслена група представлена в основному такими рисами характеру, які сприймаються у свідомості носія мови 3 негативною оцінкою. Це пояснюємо тим, що зі зміною релігійної системи, еволюцією культури змінюється й ставлення до тварини: від ідеалізації та обожнення людина переходить до приписування тваринам негативних рис. Крім того, правильна поведінка людини й позитивні риси характеру сприймаються як норма, проте негативні риси характеру чи непристойна поведінка завжди засуджуються, що й отримало вияв у фразеологічній системі української та російської мов. 


\title{
Література:
}

1. Левченко О. П. Фразеологічна символіка: лінгвокультурологічний аспект: монографія. - Л. : ЛРІДУ НАДУ, 2005. 263 с.

2. Маслова В. А. Лингвокультурология: учеб. пособие для студ. вузов. 2-е изд. М. : Академия, 2004. 204 с.

3. Фёдоров А. И. Фразеологический словарь русского литературного языка: ок. 13000 фразеологических единиц. 3-е изд., испр. М. : Астрель: ACT, 2008. $878 \mathrm{c}$.

4. Фразеологічний словник української мови. У 2-х кн. / Уклад.: В. М. Білоноженко та ін. К. : Наук. думка, 1993.

5. Хайруллина P. Х. Фразеологическая картина мира: от мировидения к миропониманию: монография. 2-е изд. Уфа: изд-во БГПУ, 2008. 300 c.

DOI https://doi.org/10.30525/978-9934-26-039-1-13

\section{ЛІНГВОФІЛОСОФСЬКІ ЗАСАДИ КОНЦЕПТУАЛІЗАЦЇ̈ ПОНЯТТЯ «МОВЛЕННЯ»}

\author{
Скрипник Н. I. \\ кандидат філологічних наук, \\ завідувач кафедри украӥнської філології \\ КЗВО «Вінницький гуманітарно-педагогічний коледж» \\ м. Вінниця, Україна \\ Хом'як I. М. \\ доктор педагогічних наук, \\ академік Академії наук вищої школи України, \\ професор кафедри української мови і літератури \\ Національний університет "Острозька академія» \\ м. Острог, Рівненська область, Украӥна
}

Мова як унікальне антропологічне біосоціальне явище привертала увагу мислителів і науковців 3 давнини: від філософів Античності, Стародавнього Китаю, Індії та світочів інших цивілізацій - до власне лінгвофілософського періоду XIX століття й «дискурсивного перевороту» $\mathrm{XX}$ - XXI ст. Значення й філософські виміри мови з самого початку поєднувалися зі спостереженнями за власне лінгвістичними закономірностями на рівні із рефлексіями світобудови й буття людини. 